\title{
The Loading Capacity of the Elands River: A Case Study of the Waterval Boven Wastewater Treatment Works, Mpumalanga Province, South Africa
}

\author{
Sandile Dlamini1 ${ }^{*}$, Thomas K. Gyedu-Ababio', Andrew Slaughter ${ }^{2}$ \\ ${ }^{1}$ Inkomati-Usuthu Catchment Management Agency, Mbombela, South Africa \\ ${ }^{2}$ Institute for Water Research, Rhodes University, Grahamstown, South Africa \\ Email: *dlaminis@iucma.co.za, thomasga@iucma.co.za, a.slaughter@ru.ac.za
}

How to cite this paper: Dlamini, S., Gyedu-Ababio, T.K. and Slaughter, A. (2019) The Loading Capacity of the Elands River: A Case Study of the Waterval Boven Wastewater Treatment Works, Mpumalanga Province, South Africa. Journal of Water Resource and Protection, 11, 1049-1063.

https://doi.org/10.4236/jwarp.2019.118062

Received: June 10, 2019

Accepted: August 23, 2019

Published: August 26, 2019

Copyright $\odot 2019$ by author(s) and Scientific Research Publishing Inc. This work is licensed under the Creative Commons Attribution International License (CC BY 4.0).

http://creativecommons.org/licenses/by/4.0/

\begin{abstract}
Nutrient loads into water resources continues to be a major problem in Southern Africa. This has resulted in significant compromises in the ecological integrity of freshwater resources. The study aimed to assess the pollution load into the Elands River in terms of nitrates and orthophosphates. These variables were compared against the Crocodile Catchment Interim Resource Quality Objectives to determine compliances or non-compliance of the Waterval Boven wastewater treatment plant. Generally upstream nitrate levels did not exceed the ideal limit of $0.5 \mathrm{mg} \cdot \mathrm{l}^{-1}$ as indicated in the 2015 to 2016 samples where values ranged between $0.32 \mathrm{mg} \cdot \mathrm{l}^{-1}$ and $0.27 \mathrm{mg} \cdot \mathrm{l}^{-1}$, respectively. Similarly, observed upstream orthophosphates levels were below the ideal limit of $0.03 \mathrm{mg} \cdot \mathrm{l}^{-1}$. However, downstream values of both nutrients exceeded the respective set limits. The nutrient load contribution from the sewage plant was characterised by a simple point-source model. Patterns of the loads into the river were demonstrated on a load duration curve based on the river which equalled or exceed $0.18 \mathrm{~m}^{3} / \mathrm{s}$ upstream and $1.31 \mathrm{~m}^{3} / \mathrm{s}$ downstream at $90 \%$ of the time. However, the flows were regarded as significantly low to deal with uncontrolled pollution loads. Most of the observed loads fell below the ideal limit of $0.05 \mathrm{mg} \cdot \mathrm{l}^{-1}$ for nitrates both upstream and downstream of the sewage plant. For orthophosphates, most of the upstream loads were below the tolerable limit of $0.1 \mathrm{mg} \cdot \mathrm{l}^{-1}$ whilst the downstream loads were exceeding the tolerable limits. The higher loads downstream in the river were attributed to the sewage discharge from the Waterval Boven wastewater treatment plant and the low river flows. Hence it could be concluded that river water quality should be interpreted based on the river flow regime in a given season.
\end{abstract}




\section{Keywords}

Loading Capacity, Flow Duration Curve, Load Duration Curve, Exceedance

\section{Introduction}

The global availability of freshwater is facing numerous threats. These threats emanate from various factors, such as the uneven distribution of rainfall, increased population demand, increased economic demand and mostly uncontrolled pollution into water resources [1] [2] [3] [4]. It is believed that uncontrolled pollution poses the most freshwater challenges in Southern Africa. The pollution originates from both point sources such as waste water treatment plants (WWTPs) and non-point sources such as agricultural run-off from land [5]. Hence the first and most readily-achievable step to managing water quality is to properly manage waste water treatment plants (WWTPs) [6].

Studies agree that South Africa is an arid country with relatively little runoff from rainfall events and therefore loads of pollutants from WWTPs disproportionately affect the water quality of rivers with minimal dilution effect [7] [8]. The Department of Water and Sanitation also alluded that nutrient enrichment and microbial contamination in South Africa are generally associated with water resources that receive large volumes of poorly-treated sewage [9]. [10] concurs that nutrient enrichment, particularly from untreated or partially treated wastewater is very common phenomenon. Several authors do attest that the problem is widespread among developing countries [10] [11] [12] [13]. It is commonly accepted that there is an existing relationship between river flows and water quality. At low flows, there is often a reduced dilution capacity and contaminants easily exceed acceptable threshold concentrations. When low river flows receive high volumes of wastewater effluents from WWTPs or feeder tributaries there is a significant decline in water quality status [8]. As stated by [14], there is often a link between river health problems and flow regimes.

Several models have been developed to determine the pollution loading into water resources. One of the models is the Load Duration Curve (LDC) which was developed to determine the relationship between water quality and water flow. Researchers have been able to use the LDC as an analysis tool to investigate the current and future impact of nutrient load into rivers [15] [16].

\section{Materials and Methods}

The Elands River traverses quaternary X21G of the Crocodile East catchment, on coordinates $25^{\circ} 38^{\prime} 8.18^{\prime \prime} \mathrm{S}, 30^{\circ} 20^{\prime} 31.22^{\prime \prime} \mathrm{E}$. It passes near the town of Waterval Boven before it confluences with the Crocodile River (Figure 1). The study focused on the Waterval Boven wastewater treatment plant which is located on the southern part of the town (coordinates $25^{\circ} 38^{\prime} 10.26^{\prime \prime S}, 30^{\circ} 20^{\prime} 35.38^{\prime \prime} \mathrm{E}$ ) and services the town and its surrounding townships. 


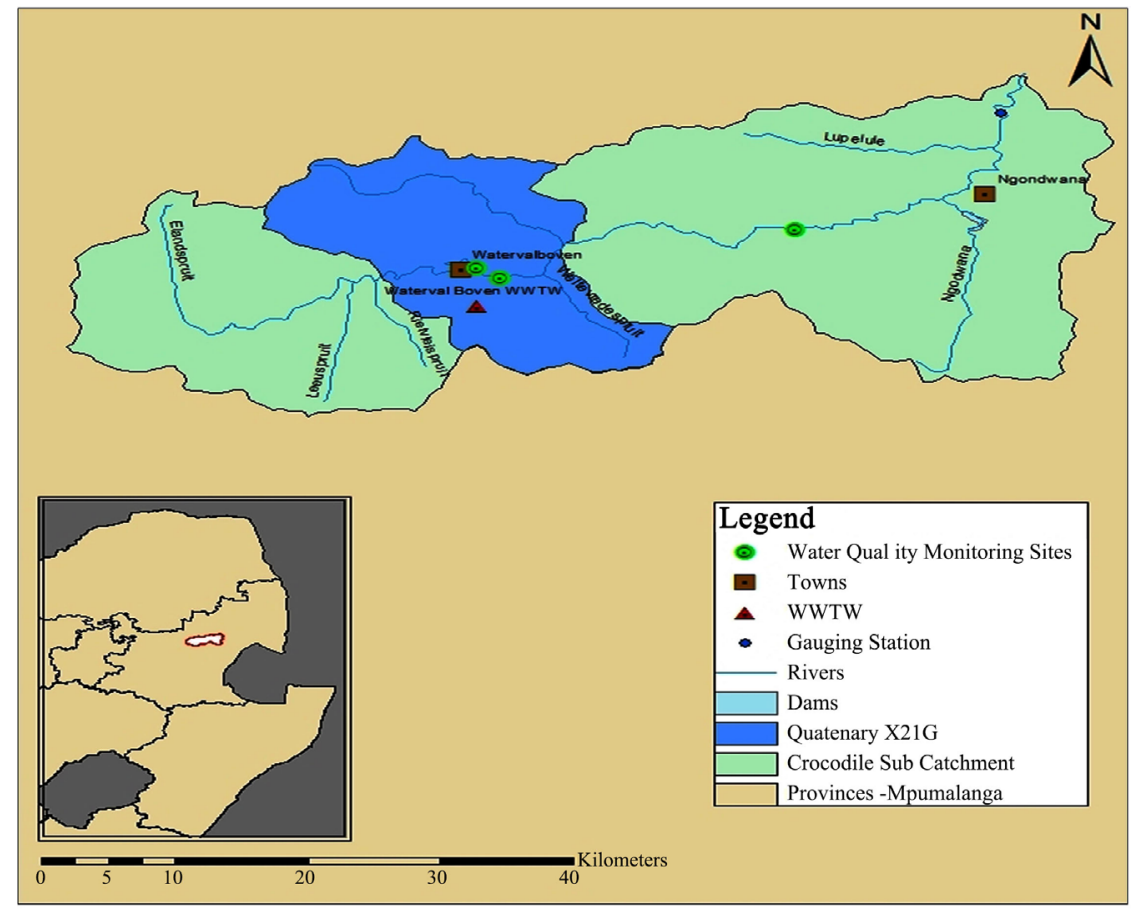

Figure 1. Study area.

\subsection{Water Quality}

The study used historical water quality data from 2008 to 2016, obtainable from the Department of Water and Sanitation (DWS) and the Inkomati-Usuthu Catchment Management Agency (IUCMA). The data had been collected according to the guidelines as described by the American Public Health Association [17] and Department of Water Affairs \& Forestry [18]. The monitoring points are situated upstream, at the discharge point and downstream of the WWTP on the Elands River.

Water quality results were compared to the Crocodile Interim Water Quality Resource Objectives (RQOs) and the recently gazetted Inkomati resource quality objectives [19]. Whilst the recently gazetted objectives may not cover all parameters of concern, the gaps were addressed by the National Target Water Quality Guidelines (TWQG) [18].

\subsection{Water Quantity Data}

The study used historical monthly flow data from 1957 to 1999 from the DWS gauging stations X2H011 (upstream of Waterval Boven WWTP) and X2H015 (downstream of Waterval Boven WWTP). The data was used to establish the flow regimes along the Elands River and to formulate the necessary graphs, namely; Flow Duration Curve and Load Duration Curves. Data was then analysed based on seasonal patterns (wet or dry periods) [20].

\subsection{Flow Duration Curve (FDC)}

The FDCs were generated using the river flow data, which was sorted in a de- 
scending order and ranked according to flow values in Ms Excel. The exceedance probability for each daily flow was computed using the following formula in Equation (1):

$$
P=\left[\frac{M}{(n+1)}\right] 100
$$

$P=$ the probability that a given flow will be equalled or exceeded (\% of time)

$M=$ assigned rank number

$n=$ the total number of days for period of record

[21] [22].

The FDC was plotted with calculated $P$ values on the $\mathrm{X}$-axis (\% equalled or exceeded) and corresponding flow values on the $\mathrm{Y}$-axis $\left(\mathrm{m}^{3} \cdot \mathrm{s}^{-1}\right)$.

Load duration curve ( $L D C)$

The load duration curves were developed using the $P$ values calculated from the FDC Loads corresponding to a water quality limit were plotted in $\mathrm{kg} \cdot \mathrm{day}^{-1}$. The loads of the LDC are calculated based on the formula:

$$
\text { Load }=Q \times \text { water quality limit } \times \text { conversion factor }
$$

where $Q$ is daily flow $\left(\mathrm{m}^{3} \cdot \mathrm{s}^{-1}\right)$, the water quality limit would typically be a concentration (mg. $\mathrm{l}^{-1}$ ) and the conversion factor would be to convert between the concentration, volume and time units to derive the load in $\mathrm{kg} \cdot \mathrm{day}^{-1}$. For $\mathrm{Q}$ in $\left(\mathrm{m}^{3} \cdot \mathrm{s}^{-1}\right)$ and water quality limit in $\mathrm{mg} \cdot \mathrm{l}^{-1}$, the conversion factor would typically be $60 \mathrm{sec} \times 60 \mathrm{~min} \times 24 \mathrm{~h} \times 1000 \mathrm{l} / 1000,000 \mathrm{mg}$. The LDC is constructed by plotting the $P$ values (\%) derived from (1) on the $\mathrm{X}$-axis and load values derived from (2) on the Y-axis [16].

\subsection{Point-Source Modelling}

The nutrient load contribution of the Waterval Boven WWTP was characterised by a simple point-source model based on the model by [23]. Conceptually, the model is based on the fact that effluent flow and nutrient concentrations from any identified point source in South Africa appear to be random over time, which could be related to inconsistent management of WWTPs in South Africa. The model uses four parameters, $Q_{p \max }$ and $Q_{p \min }\left(\mathrm{m}^{3} \cdot \mathrm{s}^{-1}\right)$, representing the maximum and minimum effluent flow from all point sources affecting a particular monitoring point, respectively, and $C_{p \max }$ and $C_{p \min }\left(\mathrm{mg} \cdot \mathrm{l}^{-1}\right)$, representing the maximum and minimum nutrient concentrations of the point source effluent. The model is run on a daily time step corresponding to observed daily flow for a monitoring point. Two uniformly distributed random numbers are generated by the model, with values between 0 and 1 , to represent the variability in WWTP effluent flow and nutrient concentration with the assumption that point source flows and nutrient concentrations are independently uncertain.

The model is therefore:

$$
Q_{p s i m_{-} i}=R A N D \times\left(Q_{p \max }-Q_{p \min }\right)+Q_{p \min }
$$




$$
C_{p s i m_{-} i}=R A N D \times\left(C_{p \max }-C_{p \min }\right)+C_{p \min }
$$

where $Q_{p s i m_{-} i}$ is the point source effluent flow for day i. $C_{p s i m_{-} i}$ is the point source nutrient concentration for $\mathrm{day}_{F}$, and RAND is a random number between 0 and 1, with independent random numbers being generated for Equations (3) and (4). The instream simulated nutrient concentration which can be compared to observed data and then be calculated as:

$$
C_{\text {sim_ }_{-} i}=\left(C_{\text {sim_i }_{-} i} \times Q_{p s i m_{-} i}\right) / Q_{i}
$$

where $C_{\text {sim_i }}$ represents the simulated instream nutrient concentration $\left(\mathrm{mg} \cdot \mathrm{l}^{-1}\right)$ on day $i$ and $Q_{i}$ represents the total flow in the river $\left(\mathrm{m}^{3} \cdot \mathrm{s}^{-1}\right)$ on day $i$. The model is implemented in Microsoft Excel. The values of $Q_{p \max }$ and $Q_{p \min }$ and $C_{p \max }$ and $C_{p \min }$ are manipulated manually until the simulated nutrient concentrations show a similar trend of decreasing concentration with increasing flow (dilution) as evident in the observed data and the values of these parameters can be guided by any information available for a particular point source such as monitored effluent flow or nutrient concentration and WWTP treatment capacity.

\subsection{Data Analysis}

Water quality data was populated and analysed using Microsoft Excel. Graphs showing patterns of the water quality status of the study area were produced and assessed against the Crocodile River Catchment's interim resource quality objectives [24]. Annual averages and standard deviations for each parameter were computed.

\section{Results}

The Crocodile Interim Resource Quality Objectives, Target Water Quality Guidelines and Inkomati Resource Quality Objectives (RQOs) were considered for discussions.

\subsection{Nitrates}

The nitrates limits used in this discussion are indicated in Table 1.

Figure 2 shows the nitrate values upstream (U/S) of the WWTP, at the WWTP discharge point (DP) and downstream of the WWTP (D/S). The upstream values were generally within the interim RQOs. The 2008 water quality results indicate that nitrate concentrations averaged $0.32 \mathrm{mg} \cdot \mathrm{l}^{-1}\left( \pm 0.12 \mathrm{mg} \cdot \mathrm{l}^{-1}\right)$ with a highest value of $0.50 \mathrm{mg} \cdot \mathrm{l}^{-1}$ in the month of July. The concentration slightly increased in 2009 where values averaged $1.04 \mathrm{mg} \cdot \mathrm{l}^{-1}\left( \pm 1.17 \mathrm{mg} \cdot \mathrm{l}^{-1}\right)$ with a highest value of $4.10 \mathrm{mg} \cdot \mathrm{l}^{-1}$ in July. The year 2010 and 2011 also experienced significantly high values of average $0.74 \mathrm{mg} \cdot \mathrm{l}^{-1}\left( \pm 1.10 \mathrm{mg} \cdot \mathrm{l}^{-1}\right)$ and $0.57 \mathrm{mg} \cdot \mathrm{l}^{-1}( \pm 1.17$ mg. $\mathrm{l}^{-1}$ ), respectively. The high values were experienced between February and May in 2010, whereas in 2011, nitrate concentrations were higher in January and February which coincides with the wet season [25]. 
The average nitrate concentration was $7.45 \mathrm{mg} \cdot \mathrm{l}^{-1}\left( \pm 2.74 \mathrm{mg} \cdot \mathrm{l}^{-1}\right)\left(\mathrm{NO}_{3}-\mathrm{DP}\right.$ graph) at the discharge point. However an average concentration of $14.20 \mathrm{mg} \cdot \mathrm{l}^{-1}$ was recorded in 2008. Overall the values from the discharge point were significantly exceeding all the limits indicated in Table 1.

The concentrations of nitrate downstream $\left(\mathrm{NO}_{3}-\mathrm{D} / \mathrm{S}\right.$ graph $)$ of the WWTP indicate a slight increase compared to the upstream point (as represented by the red graph). For example, in 2008, the concentrations averaged $0.52 \mathrm{mg} \cdot \mathrm{l}^{-1}( \pm 0.21$ $\mathrm{mg} \cdot \mathrm{l}^{-1}$ ) with a highest concentration of $1 \mathrm{mg} \cdot \mathrm{l}^{-1}$ compared to an average value of $0.32 \mathrm{mg} \cdot \mathrm{l}^{-1}$ upstream in the same year. Generally, values equalled or exceeded the ideal limit of $0.5 \mathrm{mg} \cdot \mathrm{l}^{-1}$.

\subsection{Orthophosphate}

Orthophosphate values were compared to the standard limits as indicated in Table 2 to determine previous compliances on the Elands River.

The orthophosphates concentrations at the upstream point $\left(\mathrm{PO}_{4}-\mathrm{U} / \mathrm{S}\right.$ graph) rarely exceeded the tolerable limits as indicated in Figure 3. However in 2008, the average orthophosphate values were above the ideal limit of $0.03 \mathrm{mg} \cdot \mathrm{l}^{-1}$ but were within the tolerable limits at $0.086 \mathrm{mg} \cdot \mathrm{l}^{-1}\left( \pm 0.076 \mathrm{mg} \cdot \mathrm{l}^{-1}\right)$. Recorded concentrations highlighted cases of exceedance in July and September with a maximum concentration of $0.2 \mathrm{mg} \cdot \mathrm{l}^{-1}$, which coincided with the dry period. Further incidents of exceedance of the limits were recorded in 2015 where values reached over $0.6 \mathrm{mg} \cdot \mathrm{l}^{-1}$.

Orthophosphate levels at the discharge point $\left(\mathrm{PO}_{4}-\mathrm{DP}\right)$ significantly exceeded the Crocodile Interim RQOs, TWQG and Inkomati RQOs as indicated in Figure 3. For example, in 2009 the average orthophosphate concentration was $2.14 \mathrm{mg} \cdot \mathrm{l}^{-1}$ $\left( \pm 1.99 \mathrm{mg} \cdot \mathrm{l}^{-1}\right)$, whereas in 2010 , the average concentration was $1.17 \mathrm{mg} \cdot \mathrm{l}^{-1}( \pm 1.52$ $\left.\mathrm{mg} \cdot \mathrm{l}^{-1}\right)$. The high values in the discharge point provide further indication of continuous disposal of sewage waste into the river.

Figure 3 further shows the concentrations of orthophosphates at the downstream point of the WWTP $\left(\mathrm{PO}_{4}-\mathrm{D} / \mathrm{S}\right.$ graph). The impact of the sewage is evident in the 2008 results, wherein the downstream concentrations were slightly higher with an average of $0.14 \mathrm{mg} \cdot \mathrm{l}^{-1}\left( \pm 0.60 \mathrm{mg} \cdot \mathrm{l}^{-1}\right)$ compared to the upstream concentrations of $0.08 \mathrm{mg} \cdot \mathrm{l}^{-1}\left( \pm 0.2 \mathrm{mg} \cdot \mathrm{l}^{-1}\right)$. The highest recorded values were in July and August, with maximum values of $1 \mathrm{mg} \cdot \mathrm{l}^{-1}$. Although concentrations in 2014 appear to have decreased with an average of $0.09 \mathrm{mg} \cdot 1-1$ ( $\pm 0.2 \mathrm{mg} \cdot \mathrm{l}-1)$, overall the levels exceeded the RQOs.

\subsection{Flow Duration Curve (FDC)}

The FDC shown in Figure 4 displays the cumulative frequency of flow data from 1957 to 1998 . Figure 4 indicates a flow rate of approximately $3.3 \mathrm{~m}^{3} / \mathrm{s}$ at $10 \%$ of the time and a flow rate of $0.18 \mathrm{~m}^{3} / \mathrm{s}$ at $90 \%$ of the time. At $50 \%$ of the time, the Elands River upstream of the Waterval Boven WWTP equalled or exceeded a flow rate of $0.83 \mathrm{~m}^{3} / \mathrm{s}$. The graph further shows that, generally, flows are low in the river. 
The flow data downstream of the sewage plant is demonstrated by Figure 5 . The results show that (10\%) of the time, the flow equalled or exceeded $13.2 \mathrm{~m}^{3} / \mathrm{s}$ whilst at $90 \%$ of the time the flow equalled or exceeded $1.31 \mathrm{~m}^{3} / \mathrm{s}$. However the flows indicate an increase compared to upstream flows. The sewage plant discharged about $2.4 \mathrm{Ml} /$ day of water containing waste per day hence contributing towards the overall Elands River flow. Hence the study noted that at $50 \%$ of the time, the flow equalled or exceeded $3.8 \mathrm{~m} 3 / \mathrm{s}$, which presents more than a $100 \%$ increase compared to the upstream flows.

\subsection{Load Duration Curves}

Figures 6-9 displays instantaneous loads calculated from historical water quality data of the Elands River and the monthly average flow data based on the date of the sample. The study examines the pattern of exceedances across the flow conditions, whether they coincide with high flows and/or with low flows. The assumption is that exceedances that coincide with low flow events indicate the influence of point sources and those under the high flow conditions may indicate influence of non-point sources. The LDC from Figures 6-9 indicate the following curves; Boundary 1 (Ideal standard limit), Boundary 2 (Acceptable standardlimit) and Boundary 3 (Tolerable standard limit).

Figure 6 shows that most of the observed data fell below the ideal limit of 0.05 $\mathrm{mg} \cdot \mathrm{l}^{-1}$ for nitrates. There were few instances where exceedances plotted above the ideal limit as much of the loads fell below the acceptable limits of $2 \mathrm{mg} \cdot \mathrm{l}^{-1}$. For example, at the 2 nd percentile, loads of $492 \mathrm{~kg} /$ day were recorded above the "ideal boundary" limit. Whilst at the 50th percentile about $10 \mathrm{~kg} / \mathrm{day}$ of loads were observed. A significant percent of the time, particularly during low flows, the majority of loads were below $10 \mathrm{~kg} /$ day and laid below the ideal limit target. The Inkomati Catchment Management Area's resource quality objectives were essentially met.

The downstream point essentially takes into consideration the impact of the sewage plant as the main source of pollution (see Figure 7). Overall, much of the observed data plotted below the ideal limit curve of $0.05 \mathrm{mg} \cdot \mathrm{l}^{-1}$ for nitrates. However, there were few observed exceedances especially during low flows. The observed data exceeding the ideal standard limit curve was however plotting below the acceptable limit curve of $2 \mathrm{mg} \cdot \mathrm{l}^{-1}$. At the 10th percentile (high flows), $422 \mathrm{~kg} /$ day of nitrates loads were observed. There were few instances of observed loads that exceeded the ideal limit during low flows, such as a load of $478 \mathrm{~kg} / \mathrm{day}$ which was observed in the 67 th percentile (low flow period). Since most of the observed loads indicate results that are below the acceptable limit curve, such results were regarded as compliant to standards.

Figure 8 and Figure 9 show the loading capacity for orthophosphate upstream and downstream of the WWTP, respectively. The observed loads plotted above the $0.03 \mathrm{mg} \cdot \mathrm{l}^{-1}$ limit (ideal boundary limits) in most cases particularly during low flows. As indicated in Figure 8, heavy loads of $30.9 \mathrm{~kg} /$ day were ex- 
perienced at the 1st percentile. However at the 90th percentile, approximately $0.37 \mathrm{~kg} /$ day of orthophosphate was received. When the loads were plotted against the national target water quality guidelines (TWQG) of $0.025 \mathrm{mg} \cdot \mathrm{l}^{-1}$, they were plotting above the curve. However, most loads were below the tolerable limit curve of $0.1 \mathrm{mg} \cdot \mathrm{l}^{-1}$.

The study demonstrated that a significant amount of the observed orthophosphate loads downstream of the sewage plant plotted above the curves/limits (Figure 9). This means that the orthophosphate loads exceeded the limits most of the time. For example at the 90th percentile, loads were estimated at 19.4 $\mathrm{kg} /$ day and were plotting above all the curves. Compared to the upstream loads, where in most cases they plotted below the tolerable limit, the downstream loads were exceedingly above the tolerable limits. Whilst between the 1st and 20th percentile, loads plotted below the tolerable limit curve, although the loads were often above the acceptable limit. Thus, at $30 \%$ to $100 \%$ of the time, most of the observed loads were plotted above all the limits.

Table 1. Water quality objectives (limits) for nitrates in the Crocodile catchment.

\begin{tabular}{ccccc}
\hline Standard & Variable & Ideal & Acceptable & Tolerable \\
\hline Croc Interim RQO & $\mathrm{NO}_{3}+\mathrm{NO}_{2}(\mathrm{mg} / \mathrm{l})$ & 0.5 & 2 & 4 \\
TWQG (1996) & $\mathrm{NO}_{3}+\mathrm{NO}_{2}(\mathrm{mg} / \mathrm{l})$ & 6 & $\mathrm{n} / \mathrm{a}$ & $\mathrm{n} / \mathrm{a}$ \\
Inkomati RQO (2016) & $\mathrm{NO}_{3}+\mathrm{NO}_{2}(\mathrm{mg} / \mathrm{l})$ & unavailable & unavailable & unavailable \\
\hline
\end{tabular}

Table 2. Water quality objectives (limits) for orthophosphates in the Crocodile catchment.

\begin{tabular}{ccccc}
\hline Standard & Variable & Ideal & Acceptable & Tolerable \\
\hline Croc Interim RQO & $\mathrm{PO}_{4}(\mathrm{mg} / \mathrm{l})$ & 0.03 & 0.05 & 0.1 \\
TWQG $(1996)$ & $\mathrm{PO}_{4}(\mathrm{mg} / \mathrm{l})$ & 0.025 & $\mathrm{n} / \mathrm{a}$ & $\mathrm{n} / \mathrm{a}$ \\
Inkomati RQO $(2016)$ & $\mathrm{PO}_{4}(\mathrm{mg} / \mathrm{l})$ & 0.025 & $\mathrm{n} / \mathrm{a}$ & $\mathrm{n} / \mathrm{a}$ \\
\hline
\end{tabular}

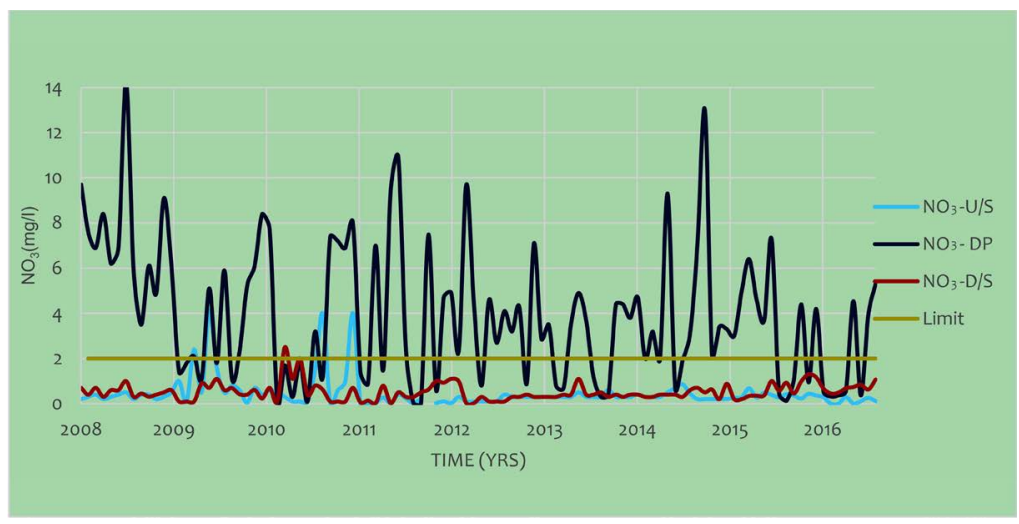

Figure 2. Nitrate concentration at the upstream, discharge point and downstream points of the Waterval Boven WWTP from 2008 to 2016. 


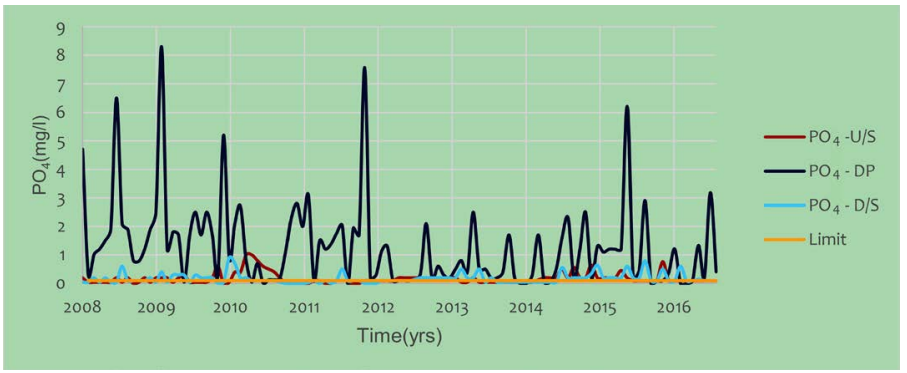

Figure 3. Orthophosphate concentration upstream, at the discharge point and downstream of the Waterval Boven WWTP from 2008 to 2016.

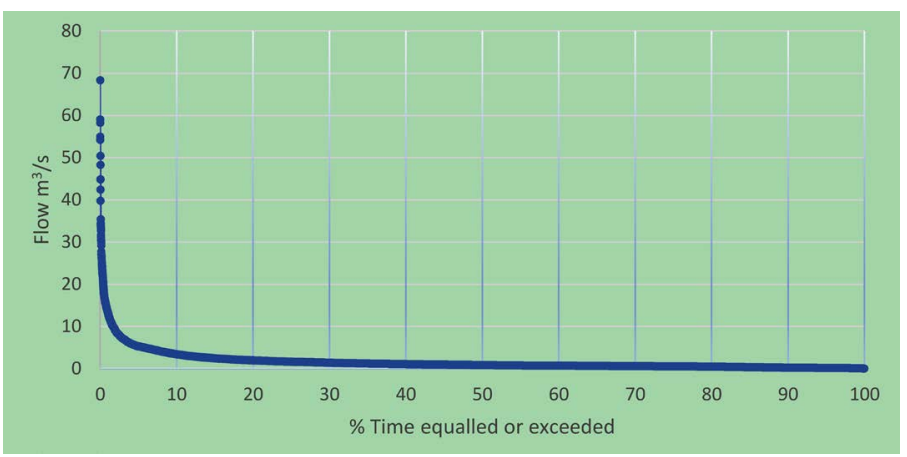

Figure 4. Flow duration curve based on flow data from 1957 to 1998 at station X2H011 (upstream of the Waterval Boven WWTP).

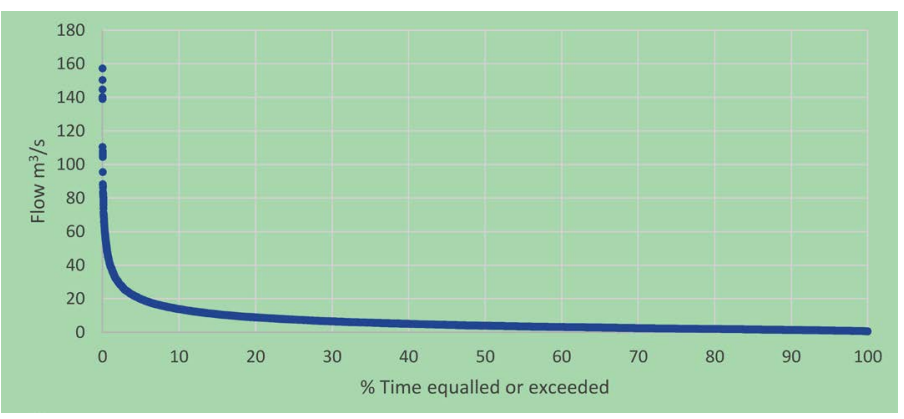

Figure 5. Flow duration curve based on flow data from 1957 to 1998 at station X2H015 (downstream of the Waterval Boven WWTP).

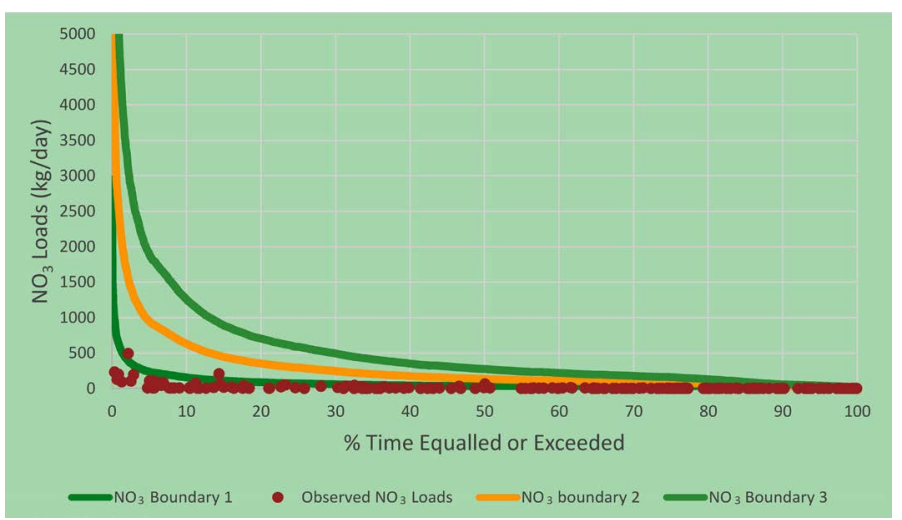

Figure 6. Nitrates loads measured upstream of the Waterval Boven WWTP on the Elands River. 


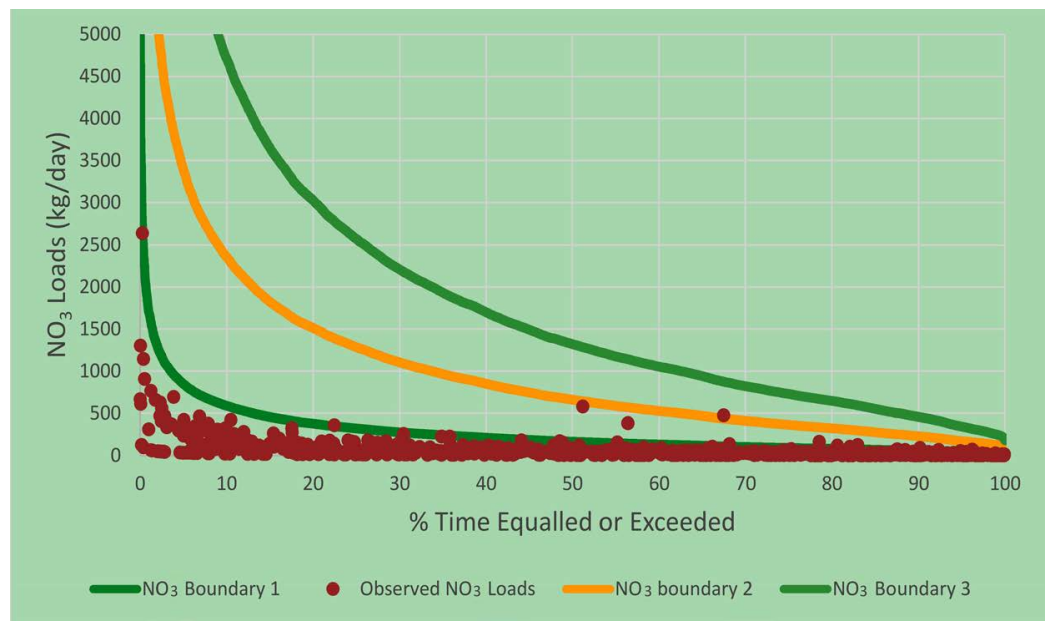

Figure 7. Nitrates loads measured downstream of the Waterval Boven WWTP on the Elands River.

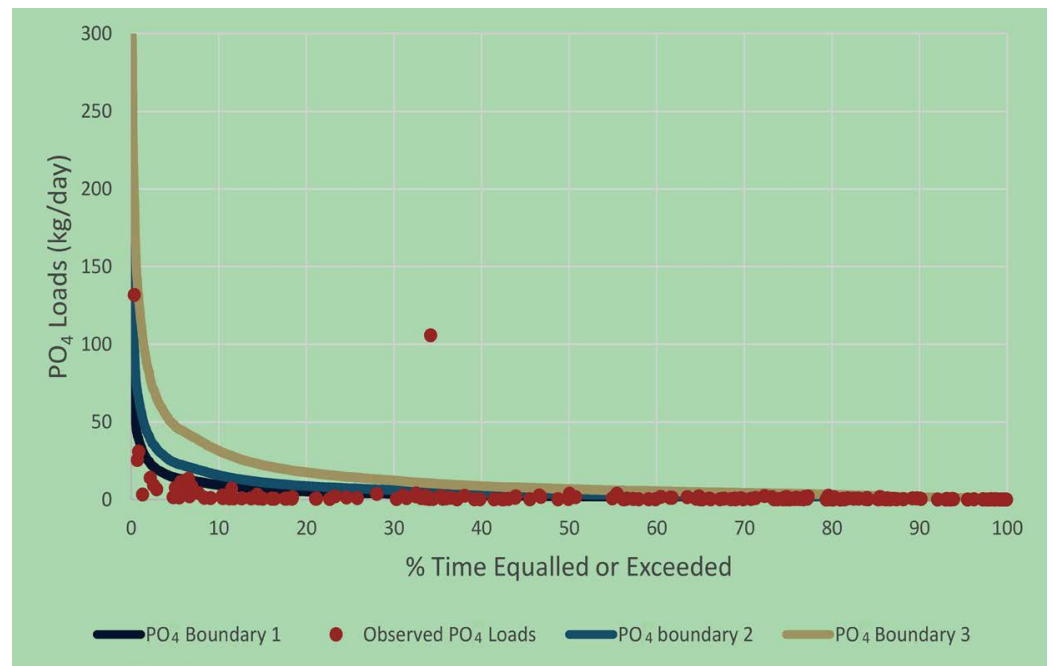

Figure 8. Orthophosphate loads measured upstream of the Waterval Boven WWTP on the Elands River.

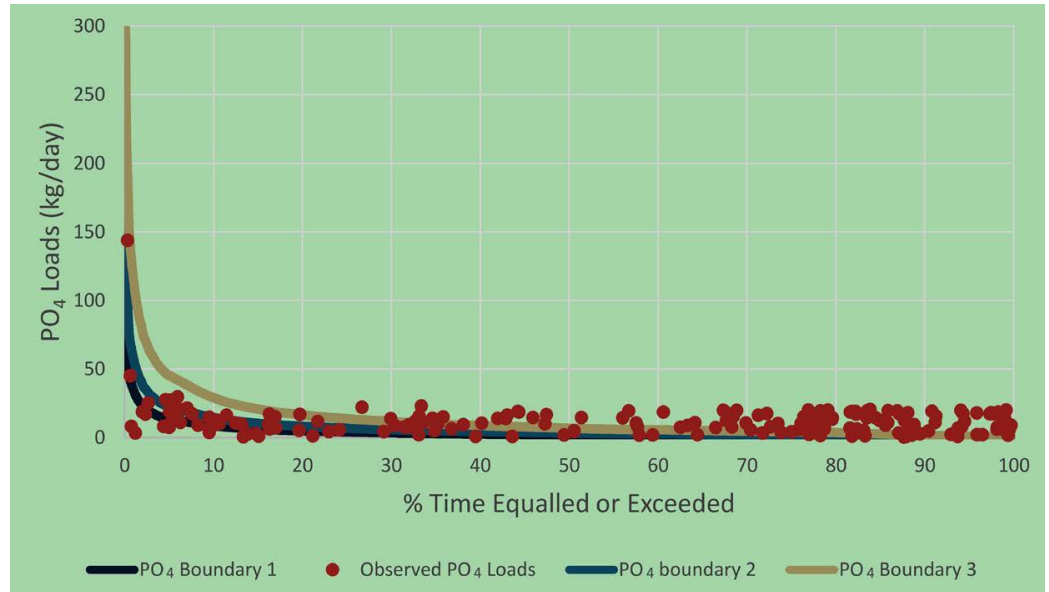

Figure 9. Orthophosphate loads measured downstream of the Waterval Boven WWTP on the Elands River. 


\section{Discussions}

The results indicate that the management of loading of the nutrients into the river during periods of low flows is critical.

\subsection{Nitrates}

Nitrates were expected to be lower upstream of the WWTP, however the contribution from non-point sources cannot be ignored. Nitrate concentrations from the WWTP discharge point $\left(\mathrm{NO}_{3}-\mathrm{DP}\right.$ graph) were significantly higher compared to the upstream and downstream concentrations. The high concentrations at the discharge point of the WWTP were not unexpected, since many components of the WWTP have often not been functioning properly during the period of the study resulting in partially treated sewage flowing into the water resources. These components included the humus tanks, trickling tanks etc. Much of these periods of high concentration coincide with the wet season, which might be indicative of additional stormwater flow into the plant and non-point sources.

\subsection{Orthophosphates}

High concentration of orthophosphate in a river often points to the presence of organic waste material [26] [27] [28]. However, overall the orthophosphates concentrations at the upstream point ranged within the tolerable levels. The WWTP discharge point ( $\mathrm{PO}_{4}$-DP graph) displayed high concentration of orthophosphates, as demonstrated in Figure 3. Most of the recorded observations exceeded the acceptable limit of $0.05 \mathrm{mg} \cdot \mathrm{l}^{-1}$, significantly. Any excessive accumulation of orthophosphates in the water indicates a high potential for eutrophication as orthophosphates enhances cellular growth in plant species [26] [29] [30] [31]. The results as observed in 2008 with a mean of $1.99 \mathrm{mg} \cdot \mathrm{l}^{-1}( \pm 1.81$ $\mathrm{mg} \cdot \mathrm{l}^{-1}$ ) are indicative of the inefficiency of the sewage plant in effectively removing the nutrients.

The downstream point of the WWTP $\left(\mathrm{PO}_{4}-\mathrm{D} / \mathrm{S}\right.$ graph) in Figure 3 further demonstrate high levels of orthophosphate concentrations which can be attributed to discharges from the WWTP, however, further contributions could be from non-point sources. The impact of the sewage is evident in the results hence the high levels of recorded orthophosphates are not unexpected.

\subsection{Flow Duration Curves}

The study area experiences both dry and wet seasons, whereby the dry season takes place from April to October and wet season from November to March. The observed flow data indicates that extended periods of low flows are not uncommon in the Elands River basin (Figure 4). Majority of the time the river flows are generally low, whereby $5 \%$ of the time, the flow barely exceeds $5 \mathrm{~m}^{3} / \mathrm{s}$. Therefore, any inflow of pollutants will have a significant effect on water quality, particularly during low flows. 


\subsection{Load Duration Curves}

Instantaneous loads were calculated based on historical water quality data of the Elands River and the daily average flow data, as indicated in Figures 6-9. All the loads that plotted above the load duration curve indicated an exceedance of the water quality objectives whilst those that appear below the curve indicate compliance to the limits.

Nitrates loads upstream plotted below the curves which imply that there were few incidences of exceedances (Figure 6). Much of the observed data fell below the ideal limit of $0.05 \mathrm{mg} \cdot \mathrm{l}^{-1}$ for nitrates. This indicates that the upstream area is less impacted as there are few sources of pollution, particularly, there are limited land use activities taking place. The downstream nitrate loads showed a considerable amount of observed nitrate loads which plotted below the curves indicating few incidences of exceedance (see Figure 7). However, the few observed exceedances during low flows might suggest an influence of a point source; in this case, it could be the sewage plant. Much of the observed loads complied with the "acceptable" limit graph.

The observed orthophosphates loads exceeded the $0.03 \mathrm{mg} \cdot \mathrm{l}^{-1}$ boundary limits in most cases particularly during low flows. This might suggest a constant point source of phosphate content upstream of the plant. However, most loads were below the tolerable curve of $0.1 \mathrm{mg} / \mathrm{l}$. Hence continuous loads might have a further negative impact on the water resource. However, the orthophosphate loads observed downstream of the sewage plant plotted above the curves (see Figure 9). Even during high flows, observed loads plotted above the ideal and acceptable loads. Therefore, the threat of eutrophication is significant downstream of the sewage plant. If the river continues to receive such loads, it might be rendered non-beneficial to downstream users.

\section{Conclusions}

The overall loading capacity of the river, at the area of concern, showed that flows and pollutant concentrations are very variable. Hence it is important to define water pollution and compliance status based on the flow regime at each season. Continuous water resource flow monitoring and water quality sampling are therefore essential to reliably determine the allowable loading pattern into water resources. Furthermore, water RQOs must not be generic. Instead, objectives must address each flow regime. Whilst in other cases data availability is a challenge, this study indicated that knowing the stream hydrology and loading rates is important for water users to easily determine the level of impairment to water bodies.

The loading capacity with regards to the two nutrients can be considered quite varying. Most literature consider orthophosphates as very critical in vegetational growth and the subsequent eutrophication hence much focus may be on the orthophosphates. Therefore, controlling the phosphate loading into the Elands River might play a major role in reducing future eutrophication. 


\section{Acknowledgements}

The authors are grateful to the Centre for Environmental Management in the University of the Free State (South Africa) and the two anonymous external reviewers whose comments and inputs resulted in a substantial improvement of this paper. This research was fully funded by the Inkomati-Usuthu Catchment Management Agency under the South African Department of Water and Sanitation. It was carried out jointly with the Institute for Water Research at Rhodes University (South Africa).

\section{Conflicts of Interest}

The authors declare no conflicts of interest regarding the publication of this paper.

\section{References}

[1] Moolman, C.E., Blignaut, J.N. and Van Eyden, R. (2006) Modelling the Marginal Revenue of Water in Selected Agricultural Commodities: A Panel Data Approach. Agrekon, 45, 78-88. https://doi.org/10.1080/03031853.2006.9523735

[2] WWF (2009) Everything You Need to Know about the UN Watercourses Convention.

[3] CSIR (2010) A CSIR Perspective on Water in South Africa. CSIR Report No. CSIR/NRE/PW/IR/2011/0012/A. Pretoria.

[4] DWA (2011) Planning Level Review of Water Quality in South Africa. Pretoria.

[5] Pastorok, R.A. and Bilyard, G.R. (1985) Effects of Sewage Pollution on Coral-Reef Communities. Marine Ecology_Progress Series, 21, 175-189.

https://doi.org/10.3354/meps021175

[6] Schölzel and Bower (1999) Small Scale Wastewater Treatment Plant Project; Report on Project Criteria, Guidelines and Technologies.

[7] Griffin, N.J., Palmer, C.G. and Scherman, P.A. (2014) Critical Analysis of Environmental Water Quality in South Africa: Historic and Current Trends. WRC Report No. $2184 / 1 / 14$.

[8] Deksissa, T., Ashton, P.J. and Vanrolleghem, P.A. (2003) Control Options for River Water Quality Improvement: A Case Study of TDS and Inorganic Nitrogen in the Crocodile River (South Africa). Water SA, 29, 209-218. https://doi.org/10.4314/wsa.v29i2.4858

[9] DWS (2016) Water Quality Management Policies and Strategies for South Africa. Water Resource Planning Systems Series: Entering an Era of Water Scarcity. The Challenges Ahead. Ecological Application, 10, 941-948. https://doi.org/10.1890/1051-0761(2000)010[0941:EAEOWS]2.0.CO;2

[10] Welch, E.B. and Lindell, T. (1980) Ecological Effects of Waste Water. Cambridge University Press, London.

[11] Moyo, N.A.G. (1997) Lake Chivero: A Polluted Lake. University of Zimbabwe Publications, Harare.

[12] Nhapi, I. and Tirivarombo, S. (2004) Sewage Discharges and Nutrient Levels in Marimba River, Zimbabwe. Water $S A, 30,107-114$. http://www.wrc.org.za https://doi.org/10.4314/wsa.v30i1.5033

[13] Bootsma, H.A. and Hecky, R.E. (1993) Conservation of the African Great Lakes: A 
Limnological Perspective. Journal Conservation Biology, 7, 645-656. https://doi.org/10.1046/j.1523-1739.1993.07030644.x

[14] Acreman, M.C. and Dunbar, M.J. (2004) Defining Environmental River Flow Requirements: A Review Hydrology and Earth System Sciences Discussions. European Geosciences Union, 8, 861-876. https://doi.org/10.5194/hess-8-861-2004

[15] Chen, L. and Schumer, R. (2010) Impact of Flow-Duration Curve Temporal Resolution on Sediment Load Estimates. 2nd Joint Federal Interagency Conference, Las Vegas, 27 June-1 July, 2010, 145-155.

[16] EPA (2007) An Approach for Using Load Duration Curves in the Development of TMDLs. Washington DC.

[17] APHA (2005) American Public Health Association. Washington DC.

[18] DWAF (1996) South African Water Quality Guidelines. 2nd Edition, Pretoria.

[19] DWS (2016) Water Quality Management Policies and Strategies for South Africa: Water Quality and Water Quality Management Challenges in South Africa. Water Resource Planning Systems Series, Edition 1, Pretoria.

[20] Cleland, B.R. (2003) TMDL Development from the "Bottom-Up" Part III: Duration Curves and Wet Weather Assessments. Proceedings of the Water Environment Federation, Chicago, 1740-1766.

[21] USGS (1969) Flow-Duration Curves Manual of Hydrology: Part 2. Low-Flow Techniques. Geological Survey Water-Supply Paper.

http://pubs.usgs.gov/wsp/1542a/report.pdf

[22] CDFW (2013) Standard Operating Procedure for Flow Duration Analysis in California. Department of Fish and Wildlife Instream Flow. Sacramento. http://www.dfw.ca.gov/water/instream_flow.html

[23] Slaughter, A.R. and Hughes, D.A. (2013) A Simple Model to Separately Simulate Point and Diffuse Nutrient Signatures in Stream Flows. Hydrology Research, 44, 538-553. https://doi.org/10.2166/nh.2012.213

[24] ICMA (2008) The Inkomati Catchment Management Strategy: Status Quo Report, Version 1. Mpumalanga.

[25] Masereka, E.M., Ochieng, G.M. and Snyman, J. (2018) Statistical Analysis of Annual Maximum Daily Rainfall for Nelspruit and Its Environs. Jàmbá: Journal of Disaster Risk Studies, 10, a499. https://doi.org/10.4102/jamba.v10i1.499

[26] Nixon, S.W. (1995) Coastal Marine Eutrophication: A Definition, Social Causes and Future Concerns. Ophelia, 41, 199-219. https://doi.org/10.1080/00785236.1995.10422044

[27] Anderson, D.M., Glibert, P.M. and Burkholder, J.M. (2002) Harmful Algal Blooms and Eutrophication: Nutrient Sources, Composition, and Consequences. Estuaries, 25, 704-726. https://doi.org/10.1007/BF02804901

[28] Kotti, M.E., Vlessidis, A.A., Thanasoulias, N.C. and Evmiridis, N.P. (2005) Assessment of River Water Quality in Northwestern Greece. Water Resources Management, 19, 77-94. https://doi.org/10.1007/s11269-005-0294-Z

[29] Smith, V.H., Tilman, G.D. and Nekola, J.C. (1999) Eutrophication; Impacts of Excess Nutrient Inputs on Freshwater, Marine and Terrestrial Ecosystem. Journal of Environmental Pollution, 100, 179-196. https://doi.org/10.1016/S0269-7491(99)00091-3

[30] Vijayvergia, R.P. (2008) Eutrophication: A Case Study of Highly Eutrophicated Lake Udaisagar, Udaipur (Raj.), India with Regards to Nutrient Enrichment and Emerging Consequences. The 12th World Lake Conference, Proceeding of Taal 2007, 
Jaipur City, 29 October-2 November 2007, 1557-1560.

[31] Dlamini, S., Nhapi, I., Gumindoga, W., Nhiwatiwa, T. and Dube, T. (2016) Assessing the Feasibility of Integrating Remote Sensing and In-Situ Measurements in Monitoring Water Quality Status of Lake Chivero, Zimbabwe. Journal of Physics and Chemistry of the Earth, 93, 2-11. https://doi.org/10.1016/j.pce.2016.04.004 